IZA DP No. 6217

The Interdependence of R\&D Activity and Debt Financing of Young Firms

Helmut Fryges

Karsten Kohn

Katrin Ullrich

December 2011 


\title{
The Interdependence of R\&D Activity and Debt Financing of Young Firms
}

\author{
Helmut Fryges
}

ZEW Mannheim

\author{
Karsten Kohn \\ KfW Bankengruppe Frankfurt \\ and IZA \\ Katrin Ullrich \\ KfW Bankengruppe Frankfurt
}

\section{Discussion Paper No. 6217 \\ December 2011}

\author{
IZA \\ P.O. Box 7240 \\ 53072 Bonn \\ Germany \\ Phone: +49-228-3894-0 \\ Fax: +49-228-3894-180 \\ E-mail: iza@iza.org
}

\begin{abstract}
Any opinions expressed here are those of the author(s) and not those of IZA. Research published in this series may include views on policy, but the institute itself takes no institutional policy positions.

The Institute for the Study of Labor (IZA) in Bonn is a local and virtual international research center and a place of communication between science, politics and business. IZA is an independent nonprofit organization supported by Deutsche Post Foundation. The center is associated with the University of Bonn and offers a stimulating research environment through its international network, workshops and conferences, data service, project support, research visits and doctoral program. IZA engages in (i) original and internationally competitive research in all fields of labor economics, (ii) development of policy concepts, and (iii) dissemination of research results and concepts to the interested public.
\end{abstract}

IZA Discussion Papers often represent preliminary work and are circulated to encourage discussion. Citation of such a paper should account for its provisional character. A revised version may be available directly from the author. 
IZA Discussion Paper No. 6217

December 2011

\section{ABSTRACT \\ The Interdependence of R\&D Activity and Debt Financing of Young Firms}

We investigate the interdependence of debt financing and R\&D activities of young firms. Using micro-level data of the KfW/ZEW Start-up Panel, our estimation results show that firm characteristics are more important than personal characteristics of the founders for explaining young firms' leverage, whereas firm characteristics and human capital of both founders and employees heavily influence R\&D intensity. Applying a bivariate Tobit model, we find that there is a positive interdependent relationship between the share of loan financing and R\&D intensity. A higher share of loan financing allows for more R\&D in young firms and, at the same time, a higher R\&D intensity allows for a higher loan share. This relationship cannot be detected by merely estimating single-equation models for R\&D intensity and debt financing.

JEL Classification: $\quad$ G32, O32, L26

Keywords: innovation financing, capital structure, business start-ups, KfW/ZEW Start-up Panel, Germany

Corresponding author:

Karsten Kohn

KfW Bankengruppe

Palmengartenstr. 5-9

60325 Frankfurt am Main

Germany

E-mail: karsten.kohn@kfw.de

\footnotetext{
* Opinions expressed in this article reflect the personal views of the authors and not necessarily those of KfW. Previous versions of this paper were presented at the FGF G-Forum 2010 in Cologne, IECER 2011 in Munich, the $31^{\text {st }}$ Babson College Entrepreneurship Research Conference 2011 in Syracuse, NY, and at the $38^{\text {th }}$ EARIE Conference 2011 in Stockholm. We thank participants for fruitful discussions. All errors are our sole responsibility.
} 


\section{Introduction}

Business start-ups and young enterprises introduce new products to the market and employ new processes for production. Engaging in research and development (R\&D) is one route to create these new products and processes. Yet young firms' capacity for internal financing of $\mathrm{R} \& \mathrm{D}$ is most likely more limited than the internal financing capacity of mature enterprises. Using debt financing can relieve internal financing constraints on R\&D activity. However, the ability of young enterprises to tap external financing sources depends on their market prospects, growth opportunities, and means of collateral—which are in turn determined by R\&D activity (e.g., Chang et al., 2009). Therefore, R\&D behaviour and decisions of young firms about debt financing should be considered interdependent.

Existing evidence in the literature regarding the interdependence of $\mathrm{R} \& \mathrm{D}$ activity and debt financing is rather limited. In an early contribution, Hutchinson (1995) elaborates on the idea that financing and investment strategies of owner-managers are interdependent because owners want to maintain control over their firms. Savignac (2008) estimates the influence of financial constraints on innovation while accounting for the possibility that the occurrence of financial constraints depends on the ex ante capital structure and economic performance of a firm. Baldwin et al. (2002), drawing on a sample of established Canadian firms, also conclude that the relation between capital structure and $R \& D$ is bidirectional. In an analysis of start-ups in the US, Winston Smith (2010) investigates the role of bank loans for new firms' financing and their subsequent innovation behaviour. She finds that a high leverage is associated with a decreasing number of new patents or new copyrights.

All in all, approaches in the innovation literature and the literature on capital structure decisions remain separated. Empirical investigations either test the influence of internal financing sources like cash flow on innovation activity (Hall, 2002; Hall and Lerner, 2010) or analyses are concerned with explaining the extent of leverage of a firm by taking into account innovation behaviour as a proxy for growth opportunities (Chang et al., 2009; Achleitner et al., 2011). In addition, existing empirical studies mostly focus on mature firms that have access to public equity and debt markets. Starts-ups and young enterprises are less often investigated in their own right, with the exception of venture capital financing of young high-tech firms. Our investigation is situated at the intersection of the different strands of literature and deals with the interdependence between $R \& D$ and debt financing of young firms. 
Our empirical contribution to the literature is threefold. First, we scrutinise financing structures of young firms, both with R\&D activities and without. Second, we explain the influence of debt finance on R\&D expenditure of young firms. Third, and most importantly, we explicitly allow for an interaction of debt financing and R\&D behaviour of young firms.

Our analysis uses firm-level data of the KfW/ZEW Start-up Panel, a unique survey data set of newly founded firms in Germany. High-tech firms are notably overrepresented in the sample of the KfW/ZEW Start-up Panel. This feature enables us to investigate the relationship between financing decisions and R\&D activities in detail, based on a large number of innovative and technology-intensive start-ups. Our estimation results show that firm-related characteristics are more important than personal characteristics of the founders for explaining young firms' loan share. On the other hand, human capital of employees and founders themselves heavily influence R\&D intensity. Applying a bivariate Tobit model, we find that the interaction between the share of loan financing and R\&D intensity is positive. A higher share of loan financing allows for more R\&D in young firms and at the same time a higher R\&D intensity allows for a higher debt share. This relationship cannot be detected by merely estimating single-equation models for R\&D intensity and the share of loan financing because there is a negative correlation of unobserved shocks to both variables of interest.

The paper is structured as follows. In the next section, we give an overview of related studies in the literature. The empirical analysis starts with a description of our data set and descriptive analyses of financing structures and R\&D activities of young firms in section 3. Estimation results for both single-equation approaches and a bivariate Tobit model are discussed in section 4. Section 5 concludes.

\section{Overview of Related Literature}

\subsection{R\&D Expenditure and Firms' Capital Structure}

Financing of innovation is a recurrent theme in the economic debate. Empirical studies rely on $R \& D$ expenditure as a proxy for innovation input. First, $R \& D$ expenditure is often found to be positively linked to innovation output (e.g., van der Panne et al., 2003; Mairesse and Mohnen, 2010, and the literature cited therein). Second, R\&D expenditure has some interesting properties with regard to financing (Hall, 2002; Hall and Lerner, 2010). It covers investments in tangible assets like laboratory equipment as well as intangible assets such as human capital of research personnel. In the latter case, $R \& D$ expenditure does not result in collateral usable for debt financing. In addition, R\&D expenditure has to be financed immediately while innova- 
tion output is uncertain and cash-flow resulting from innovation projects is realised in future periods only, sometimes with a considerable time lag.

Several studies pay special attention to restrictions of innovation activity. It is stressed that internal resources and in particular cash flow are the main sources for innovation financing (e.g., Czarnitzki and Hottenrott, 2011; Savignac, 2008; Czarnitzki, 2006; Bond et al., 2005; Hottenrott and Peters, 2011; Kamien and Schwartz, 1982; Himmelberg and Petersen, 1994; Jensen and Meckling, 1976). Yet outside finance plays a role as well. On the one hand, limitation of external financing may hamper innovation activity (Gorodnichenko and Schnitzer, 2010; Czarnitzki, 2006). On the other hand, debt financing disciplines borrowers by reducing free cash flow, increases the threat of bankruptcy and initiates monitoring activities of lenders that can influence innovation activity negatively (Czarnitzki and Kraft, 2009). In addition, financing innovation through external capital is difficult because innovation generates positive externalities and asymmetric information and tax issues arise if innovators and suppliers of financial capital are not identical (Hall, 2002; Hall and Lerner, 2010). These factors drive a wedge between internal and external costs of capital and can lead to underinvestment in R\&D. As a consequence, not only the availability of financing, but also the composition of the financing mix can influence $R \& D$ activity.

Besides the availability and composition of external financing, firm specifics have an impact R\&D activity. If a company is sufficiently profitable, it can draw on internal financing for R\&D expenditure and does not have to rely on outside financing. Therefore a positive relation between R\&D and profitability can be expected (Himmelberg and Petersen, 1994; Hall, 2002; Hall and Lerner, 2010). However, if a high share of available financing is invested into fixed assets other than $R \& D$ equipment, fewer resources are free to be directed into $R \& D$, which would in turn result in a lower R\&D intensity. Bigger and older firms may be expected to have a higher R\&D intensity as product and process innovations of established firms in mature markets might require intense R\&D activity (Cohen and Levin, 1989). On the other hand, R\&D activity might not be as necessary for firms with a secure market position as for young firms trying to take root in the market. Empirical results on the relationship between size, age and R\&D activities are thus mixed (see Nyström, 2009, for an overview). Moreover, as human capital is needed to perform $R \& D, R \& D$ intensity and human capital of business owners and employees are positively related (Romer, 1990).

The relationship between R\&D activity and firms' financing structure can also be argued not to go from financing to $\mathrm{R} \& \mathrm{D}$, but in the opposite direction. There are two main approaches 
competing to explain firms' capital structure and especially leverage (see Frank and Goyal, 2008, for a recent overview). First, trade-off theory assumes that equating marginal benefits and costs of debt results in an optimal level of leverage, deviations from which are reduced over time. Second, pecking order theory emphasises different degrees of asymmetric information associated with different types of external financing. In consequence, different costs of capital and different rights requested by capital suppliers result in a preference ordering of financing sources (Ross, 1977; Myers and Majluf, 1984).

Whether trade-off theory or variants of the pecking order hypothesis explain observed capital structure decisions better is still an open question (e.g., Shyam-Sunder and Myers, 1999; Chirinko and Singha, 2000; Adedeji, 2002; López-Gracia and Sogorb-Mira, 2008). However, both approaches share a number of capital structure determinants which are related to R\&D expenditure. First, growth prospects are often approximated by R\&D expenditure (e.g., Chang et al., 2009). Second, R\&D expenditure is rather allocated into intangible than into tangible assets that cannot be used as collateral. About $60 \%$ of R\&D expenditure by enterprises in Germany can be attributed to labour costs (Eurostat, 2010, own calculations). Even in the manufacturing industry and in knowledge-intensive service sectors only one third of innovation spending goes into capital equipment—including intangible assets like patent rights-, whereas two thirds go into expenditure on personnel and service agreements with third parties (Rammer, 2009: 35). Third, empirical studies find a positive relation between innovation inputs like $R \& D$ expenditure on the one hand and firm profitability resp. productivity on the other (e.g., Czarnitzki and Kraft, 2010; Geroski et al., 1993; Hall et al., 2009). So there are different mechanisms for R\&D expenditure to influence financing leverage. ${ }^{1}$

\subsection{Particular Properties of Young Firms}

Analyses of business start-ups have to take into account special characteristics of young and small firms. This is particularly important for financing decisions. First, capital structure theories predict an influence of firm age and firm size on leverage. According to trade-off theory, debt financing should be positively related to firm size because larger firms exhibit a smaller probability of default (López-Gracia and Sogorb-Mira, 2008; Cole, 2008). Empirical evidence generally supports this hypothesis (Cassar, 2004). Second, potential information asymmetries between lenders and entrepreneurs decrease as firms mature, since older firms can provide lenders with more information about the acceptance of their products in the market and about

\footnotetext{
${ }^{1}$ Note that the respective effects on firms' debt share implied by trade-off theory or pecking order theory can be contradictory.
} 
their performance in terms of sales or profits. In addition, start-up investments require a higher financing volume than early follow-up and expansion investments. Therefore, there should be a negative relationship between firm age and loan financing according to pecking order theory (Petersen and Rajan, 1994). Higher financing needs and a lower probability of receiving external financing generate opposing influences on the structure of start-up financing.

Start-ups and young enterprises are largely dependent on their owners and the boundaries between firms as organisations and entrepreneurs as persons are often not clear-cut (Astebro and Bernhardt, 2003; Cassar, 2004). Financing decisions of young firms thus rely disproportionately on the preferences of the business founders, e.g. regarding risk and control over the firm (Bhaird and Lucey, 2010; Ang, 1992; Storey, 1994; Heger and Tykvova, 2009; Frielinghaus et al., 2005). Entrepreneurs' personal characteristics like gender, age, migration background or start-up experience are often included into empirical analyses of start-up financing (e.g., Achleitner et al., 2011; Kohn and Ullrich, 2010; Winston Smith, 2010; Coleman and Robb, 2009; Cassar, 2004; Blanchflower et al., 2003; Verheul and Thurik, 2001; Cavalluzzo and Cavalluzzo, 1998).

Another special aspect of start-up financing is the fact that external means are rather diversified compared to the financing mix of mature firms. A considerable share of business startups employs informal capital from family and friends besides financial means of the founders (Cole, 2008; Cosh et al., 2009; Eckhardt et al., 2006; Gompers and Lerner, 2006; Hagen et al., 2011; Hutchinson, 1995; Kohn and Spengler, 2008). In addition, start-up promotion by government and public financing programmes are readily available in Germany. This institutional setting may divert young firms' debt shares from those predicted by traditional financing theories.

An analogous argument as to the close connection between entrepreneurs as persons and firms as organisations applies to R\&D activity. Usually, founders themselves decide about expenditure on R\&D devoted to their business ideas. The decisions can again be expected to be influenced by human capital components such as educational background or previous business experience. Furthermore, entrepreneurs' risk aversion can play a role in face of the uncertain outcome of R\&D activity. However, Heaton and Lucas (2004) argue that a substitution of internal financing by debt lowers entrepreneurs' personal exposure to firms’ idiosyncratic risk, increasing the incentive to carry out a risky R\&D project. According to Hellmann and Puri (2000) the use of outside equity induces young firms to introduce innovative products to the market faster than firms obtaining financial means from other sources of financing. 


\section{Data and Descriptive Analyses}

This paper's empirical investigation uses data from the first two waves of the KfW/ZEW Start-up Panel (KfW/ZEW-Gründungspanel), a unique data set built up recently by the Centre for European Economic Research (ZEW), KfW Bankengruppe (Germany's largest stateowned promotional bank) and Creditreform (Germany's largest credit rating agency). The KfW/ZEW Start-up Panel is a large-scale yearly telephone survey (computer-aided telephone interviews, CATI) of young firms in Germany. It covers newly founded legally independent firms that are run by at least one full-time entrepreneur. De-mergers and subsidiaries are excluded from the survey. ${ }^{2}$

The sample of the KfW/ZEW Start-up Panel is stratified by three criteria: industry (10 sectors as defined in Table 6 in the appendix), year of firm formation, and whether or not the firm has been promoted by KfW. The design of the survey offers two main advantages for the purpose of this paper. First, while the panel covers almost all industry sectors, ${ }^{3}$ one half of all firms included in the stratified sample operate in a high-technology industry. Therefore, young technology-based firms which are of particular interest to the study of R\&D activity are notably overrepresented in the data. Second, the survey questionnaire collects not only detailed information on firm specifics but also personal information about the entrepreneurs, including their human capital endowment and personal wealth. The latter in particular may be an important driver of financing patterns.

The first survey wave was conducted in the year 2008, collecting data on 5,508 firms founded in the period from 2005 to 2007. The second survey wave, conducted in 2009, included firms from the foundation cohorts 2005 to 2008 and resulted in a net sample size of 5,638 firms. In this paper we use a pooled data set containing data from both the first and the second survey wave. $^{4}$

\footnotetext{
${ }^{2}$ See Fryges et al. (2010) for a detailed description of the design of the KfW/ZEW Start-up Panel.

${ }^{3}$ The only sectors excluded are agriculture, mining and quarrying, electricity, gas and water supply, health care, and the public sector.

${ }^{4}$ Descriptive statistics reported below use population weights in order to account for the stratification design of the KfW/ZEW Start-up Panel. As unweighted sample results are likely to deviate from the results documented in the text, we also report unweighted descriptives in the appendix (Table 7 and Table 8 corresponding to Table 1 and Table 2). Throughout the paper, all statistics of absolute values are calculated without extreme values below the 1st or above the 99th percentiles. Only the variable 'number of employees' does not exclude largest values. The inclusion of firms with one per cent lowest or highest values basically leads to the same conclusions (results available from the authors on request).
} 


\subsection{Financing Structure of Young Firms}

In the course of the survey interview, firms are asked to indicate the amount of money they spent, on the one hand, on investment in fixed assets and, on the other hand, on operating costs. Both data are measured for the calendar year prior to the survey year. Expenditure on investment and operating costs sum up to firms' total financing needs. On average, financing needs of young German firms amount to about 112,000 Euro per year. The median amounts to only 36,000 Euro. Therefore, the distribution of financing needs is highly skewed to the right. One reason for this observation is the fact that financing needs also contain salaries for employees-while $45 \%$ of all young firms do not have any employees. Moreover, in case of sole proprietorships or private companies, owners' income is paid from firms' profits and is not part of operating costs. As a consequence, many firms have only small financing needs: $37 \%$ of firms exhibit financing needs of 20,000 Euro or less per year.

With respect to the sources of financing, the questionnaire follows a two-stage approach. At the first stage, three types of financial resources are distinguished: revenues generated from sales or retained earnings, founders' own means (such as personal savings used for firm startup), and capital from external third-party providers. Firms indicated whether or not they used the different sources and-if so-the shares of total financing needs covered by the respective sources. At the second stage, the questionnaire differentiates nine sources of external financing: overdraft credits, long-term bank loans, promotional loans from KfW or financial institutions of the German states, gifts and loans from relatives and friends, subsidies from the Federal Employment Agency, equity capital, mezzanine capital, and other sources of external financing. ${ }^{5}$ Again, firms are asked to indicate whether or not they used particular sources to cover their external financing needs, and the corresponding volume shares in external capital from third-party providers. ${ }^{6}$

Table 1 summarises firms' financing structure. 92\% of firms generate revenues from sales (first column of Table 1) and on average, firms cover three fourths of their financing needs by this source (second column of Table 1). The median of this share amounts to $100 \%$, i.e. operating costs and expenditure for investments are usually financed completely from internal

\footnotetext{
${ }^{5}$ Regarding the latter residual category, only a very small number of firms (48 observations) reported to have used 'other sources'. These firms are disregarded in our empirical analysis.

${ }^{6}$ Note that the approach does not focus on the point in time when owners or other third parties provide financial means to the firms. Instead, the focus is on the calendar year in which the provided capital is actually used to cover the firms' financing needs. For example, a firm may receive a high amount of venture capital or a large bank loan in its start-up year, but use this money to finance expenditures in both the first and subsequent business years.
} 
sources. On the other hand, the $10^{\text {th }}$ percentile of this value is equal to $5 \%$. During their first years of existence a significant percentage of young firms in Germany cover only a small share of their expenses via sales revenues.

Financial means provided by firms' owners are the second most important source of finance. $46 \%$ of firms use this source and the average volume share is $18 \%$ of a firm's total expenditure. Capital from third-party providers is used by $27 \%$ of firms. Related to all firms, the average share of third-party capital in total financing is about $8 \%$. However, the importance of third-party capital varies significantly among firms. If we confine our sample to those firms which actually use at least one third-party capital provider, the average share reaches a value of $37 \%$ and $10 \%$ of firms in this reduced sample cover at least $88 \%$ of their financing needs by capital from third parties.

Table 1: Financing structure

\begin{tabular}{lcc}
\hline & $\begin{array}{c}\text { Share of all firms using the source of } \\
\text { finance (\%) }\end{array}$ & Average share in total financing (\%) \\
\hline $\begin{array}{l}\text { Revenues from sales/retained } \\
\text { profits }\end{array}$ & 91.6 & 74.5 \\
Founders' own means & 45.8 & 17.5 \\
Capital from third parties & 27.2 & 8.0 \\
\hline
\end{tabular}

\begin{tabular}{lcc}
\hline & $\begin{array}{c}\text { Share of all firms using capital from } \\
\text { third parties (\%) }\end{array}$ & $\begin{array}{c}\text { Average share in total capital received } \\
\text { from third parties (\%) }\end{array}$ \\
\hline Bank loans & 69.7 & 57.7 \\
Promotional loans & 10.8 & 6.0 \\
Relatives and friends & 27.7 & 17.2 \\
Subsidies from Federal & 28.6 & 15.6 \\
Employment Agency & 5.9 & 3.6 \\
Equity capital & 74.1 & 63.7 \\
\hline
\end{tabular}

Population-weighted results. ${ }^{\mathrm{a}}$ Bank loans and promotional loans.

Data source: KfW/ZEW Start-up Panel.

Among the various sources of external finance from third parties, traditional bank loans (overdraft credits and long-term bank loans) are of particular importance. Among those firms which actually use capital from third parties, 70\% use bank loans (lower panel of Table 1). On average, bank loans account for 58\% of total third-party financing. A corresponding $11 \%$ of firms benefit from promotional loans (from $\mathrm{KfW}$ or institutes of the states). $6 \%$ of external capital from third parties is, on average, allocated to promotional loans. 
Gifts and loans from relatives and friends as well as start-up subsidies from the Federal Employment Agency also contribute notably to external financing. The average share of thirdparty capital that is provided by relatives and friends amounts to $17 \%$, subsidies from the Federal Employment Agency for formerly unemployed persons average to $16 \%$. Yet the amount of subsidies from the Federal Employment Agency is usually small. For individual firms, these subsidies may play a substantial role in financing, in particular for very small firms set up by formerly unemployed persons. However, regarding the total volume of financial capital young firms are endowed with, subsidies for unemployed persons play a subordinate role.

Equity capital from venture capital companies or business angels (including mezzanine capital) accounts for only a small average share in third-party financing (4\%). This result is due to the fact that only $6 \%$ of firms receiving capital from third parties are financed by venture capital companies or business angels. Nevertheless, those firms which actually benefit from equity capital may receive a substantial amount of money from venture capital companies for financing R\&D activities.

In the econometric model in section 4, financial leverage is measured by the share of loan financing in total financing needs. Loan financing combines four sources of financing: overdraft credits, long-term bank loans, and promotional loans from KfW and from financial institutions of the German states. The last row of Table 1 displays that $74 \%$ of all firms using external capital from third-party providers rely on loan financing. Loans account for the lion's share of third-party financing: About 64\% of total third-party capital stems from bank loans or promotional loans.

\subsection{R\&D Activities in Young Firms}

$13 \%$ of the firms carried out own R\&D activities in the year of observation. Firms with R\&D activities spend an average of 24,300 Euro per annum on R\&D (Table 2). Expenditure on $R \& D$ includes expenses for investments in machinery or facilities for $R \& D$ projects, labour costs for personnel involved in R\&D activities, and payments to third parties for R\&D contracts. The distribution of $R \& D$ expenditure is highly skewed to the right: One half of firms with own R\&D activities spend 10.000 Euro or less on R\&D, whereas the one percent of firms with highest R\&D expenditure spends 200.000 Euro or more. 


\begin{tabular}{lccccc}
\hline & M of ob- & \multicolumn{3}{c}{ Percentiles } \\
& $\begin{array}{c}\text { Mervations } \\
\text { serven }\end{array}$ & $25 \%$ & $50 \%$ & $75 \%$ \\
\hline R\&D intensity (\%) & 1,748 & 24,300 & 2,000 & 10,000 & 25,000 \\
Rerage expenditure on R\&D (Euro) & 1,383 & 24.7 & 1.7 & 7.0 & 20.8 \\
\hline
\end{tabular}

Population-weighted results. Numbers referring to firms conducting own R\&D activities. R\&D intensity measured as expenditure on R\&D over total sales. R\&D expenditure and total sales are trimmed by excluding values above the 99th percentiles. Data source: KfW/ZEW Start-up Panel.

In the econometric model below we analyse firms' $R \& D$ intensity as defined by the ratio of R\&D expenditure to total sales. This measure scales different firm sizes in the analysis of R\&D activity. As reported in Table 2, the mean R\&D intensity of firms with own R\&D activities is $25 \%$, the corresponding median $7 \%$. However, since the firms in our sample are very young, there are firms whose expenditure on $R \& D$ even exceeds the volume of total sales (2.5\% of firms with own R\&D activities). In some firms the development of new products or services lasts several years, with high $R \& D$ expenditure going hand in hand with only a small-sized volume of sales during firms’ initial years.

\subsection{Relationship of $R \& D$ and Financial Leverage}

Table 3 summarises the observed relationship between loan financing and R\&D activities. First, we divide our sample into two groups - firms with R\&D activities and firms that are not engaged in $R \& D$ - and compare the distribution of financial leverage for these two groups of firms. Second, we compare the distribution of R\&D intensity for those firms that use loan financing with the distribution among firms that do not use loan financing.

As reported in the upper panel of Table 3, the mean share of loan financing is higher in the group of firms without R\&D activities. This is true for both the complete sample and the reduced sample of those firms that actually use loan financing. However, the difference in means is statistically significant only in the latter case. Non-parametric Kolmogorov-Smirnov tests for stochastic dominance consider additional moments of the distributions (see Conover, 1999: 456ff.). We test three hypotheses: (1) whether the distribution of financial leverage is different for firms with and without R\&D activities at all, (2) whether the distribution of leverage among firms conducting $R \& D$ first order stochastically dominates the distribution of leverage among firms without $R \& D$ activities, and (3) the reverse case. In case of the complete sample, all three hypotheses have to be rejected. However, among firms with loan fi- 
Table 3: Loan financing and R\&D activities

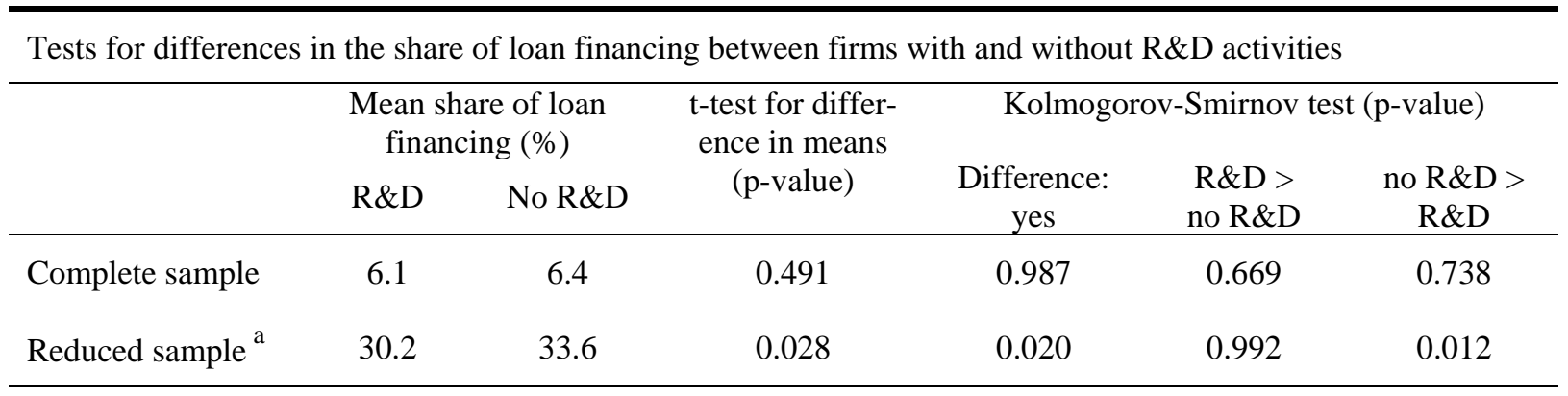

Test for differences in R\&D intensity between firms with and without loan financing

\begin{tabular}{|c|c|c|c|c|c|c|}
\hline & \multicolumn{2}{|c|}{$\begin{array}{l}\text { Mean R\&D intensity } \\
\text { (\%) }\end{array}$} & \multirow{2}{*}{$\begin{array}{l}\text { t-test for differ- } \\
\text { ence in means } \\
\text { (p-value) }\end{array}$} & \multicolumn{3}{|c|}{ Kolmogorov-Smirnov test (p-value) } \\
\hline & Loans & No loans & & $\begin{array}{l}\text { Difference: } \\
\text { yes }\end{array}$ & $\begin{array}{l}\text { Loans }> \\
\text { no loans }\end{array}$ & $\begin{array}{c}\text { No loans }> \\
\text { loan }\end{array}$ \\
\hline Complete sample & 4.8 & 7.3 & 0.320 & 0.863 & 0.991 & 0.492 \\
\hline Reduced sample $^{a}$ & 25.6 & 38.7 & 0.317 & 0.042 & 0.942 & 0.025 \\
\hline
\end{tabular}

All tests are based on unweighted sample statistics.

${ }^{a}$ The reduced sample includes all firms that actually receive loan financing (conduct R\&D activities).

Data source: KfW/ZEW Start-up Panel.

nancing, the first and the third hypothesis cannot be rejected: In bivariate comparison, firms without R\&D expenditure use a higher share of loan financing.

The lower panel of Table 3 displays corresponding results for the distributions of R\&D intensity among firms with and without financial leverage. While we observe a lower mean of $R \& D$ intensity among firms that use loan financing, the difference is not statistically significant. In addition, the Kolmogorov-Smirnov tests reject all three hypotheses of stochastic dominance in case of the complete sample. Yet in the small subsample of firms which actually do $R \& D$, we find that the distribution of $R \& D$ intensity of firms without loan financing significantly dominates the distribution of R\&D intensity of firms with a positive financial leverage: In bivariate comparison, firms that do not use loan financing have a higher R\&D intensity.

In summation, descriptive statistics show a negative relationship between loan financing and R\&D activities of young firms. This result corresponds to previous studies demonstrating that loan financing plays a subordinate role for the financing of $R \& D$ activities. Firms may rather rely on other sources like sales or retained earnings from previous years (i.e. internal financing) or, in the case of high-tech start-ups, on venture capital. Whether this result also holds in a multivariate context is examined in the regression analysis below. 


\subsection{Operationalisation of Explanatory Variables}

The literature review in section 2 emphasises that both financial leverage and R\&D intensity are determined by firm-specific characteristics like firms' tangible and intangible assets, and by specifics of the entrepreneurs such as human capital variables. We operationalise explanatory variables as follows.

Firm size is captured by the (logarithmic) number of employees including the (team of) founder(s), measured in full-time equivalents. Since the size effect is likely to be non-linear, we also include the squared value. In addition, a dummy variable characterises firms that were set up by a team of founders. Firm age is covered by a set of dummy variables indicating firms between one and four years of age.

We measure profitability by the ratio of profits to total sales. Since firms can experience losses in single years of observation, this ratio can be negative. The composition of a firm's profit depends on the legal form of the firm: In case of a private company or partnership the income of the entrepreneur is a part of the firm's profit. On the contrary, managing partners of an incorporated firm receive a salary and the firm's profit is calculated net of entrepreneurs' income. As a result, the profit-to-sales ratio may vary between firms with different legal forms. In order to account for this effect, we interact the profitability measure with a dummy variable for incorporated companies. The latter variable enters the regression equations as an additional control variable.

Tangibility of assets is approximated by expenditure on investments in fixed assets over total financing needs. Tangible assets can serve as collateral for loans and so can entrepreneurs' personal wealth. We measure entrepreneurs' personal wealth as the value of assets like personal bank deposits, bonds or real estate, net of personal debt not linked to entrepreneurial activities. Personal wealth is divided by firms' total financing needs. This measure indicates the share of a year's financing needs that can be covered by entrepreneurs' personal wealth.

Intangible assets are first measured by a dummy variable indicating whether or not firms have at least one employee working in an occupation that requires a university degree. This measure mirrors human capital among firms’ employees. Second, R\&D intensity itself serves as a proxy for intangible assets in the financing equation. Expenditure on R\&D includes investment in machines required to conduct R\&D projects. However, the majority of R\&D expenditure is allotted to personnel expenses (Rammer, 2009). Thus, R\&D intensity is appropriate to approximate the share of sales a firm spends on the creation of knowledge to gain, e.g., a competitive advantage due to a newly developed technology. Both R\&D intensity and human 
capital of firms' employees are decisive for the future development of young firms, so these two variables can also be interpreted as proxies for future growth opportunities.

However, human capital of the founders themselves might be even more important for future growth perspectives of young and small firms. Our regression models thus contain a dummy variable characterising firms in which at least one member of the team of founders has obtained a university degree. General working experience of the entrepreneurs is measured by their age (in logarithmic years). In addition, we distinguish three groups of entrepreneurs with respect to previous entrepreneurial experience: (1) those who had never started a business before; (2) those with only negative entrepreneurial experience in the sense that all former firms of the entrepreneurs failed and exited from the market; and (3) those with positive entrepreneurial experience, i.e. successful entrepreneurs who had founded at least one other firm in the past which would still be run by the entrepreneur or had been handed over to a successor or sold to an investor.

Entrepreneurs are further discriminated according to their start-up motives. We employ a standard necessity-opportunity dichotomy based on founders' own assessment. Necessity entrepreneurs start their businesses in lack of other employment alternatives, primarily in order to end unemployment or to circumvent foreseeable unemployment. In contrast, opportunity entrepreneurs are motivated primarily by the chance to commercialise a particular business idea or because they aspire to work independently. The vector of entrepreneur-specific variables is completed by two dummy variables indicating firms that were founded by female entrepreneurs and entrepreneurs with a migrational background, respectively.

Finally, our regressions include sets of dummy variables for the stratification criteria industry sector (ten sectors described in Table 6 in the appendix), year of survey wave (observation in the years 2007 and 2008), and promotion by KfW. Table 9 in the appendix documents the wording in the questionnaire for all explanatory variables and also reports mean and median values based on those observations that enter the regressions.

\section{Regression Analysis}

\subsection{Determinants of Financial Leverage: Single Equation Approach}

Since many firms do not use loan financing, the distribution of loan share has a masspoint at the value of zero. Following Wooldridge (2001: 517ff.), we use type I Tobit models to estimate the determinants of the corner solution outcomes 


$$
\text { loanshare }_{i}=\max \left(0, \text { loanshare }_{i}^{*}\right) \geq 0 \text {. }^{\circ}
$$

The latent share of loan financing loanshare $_{i}{ }^{*}$ of all start-ups $i=1,2, \ldots, N$ is specified as

$$
\text { loanshare }_{i}^{*}=\text { rdint }_{i} \gamma_{1}+z_{i} \alpha_{1}+x_{i} \beta_{1}+u_{1 i},
$$

where $r$ dint $_{i}$ denotes R\&D intensity, $z_{i}$ is a vector of explanatory firm characteristics, $x_{i}$ is a vector of personal characteristics of the entrepreneurs, and $\delta_{1}=\left(\gamma_{1}, \alpha_{1}^{\prime}, \beta_{1}^{\prime}\right)^{\prime}$ is a parameter vector. Assuming normality of the error term $u_{1 i}$, the model can be estimated via maximum likelihood. The results of this regression are depicted in columns (1) and (2) in Table $4 .^{7}$

Specification (1) includes a full set of firm and entrepreneur-related characteristics. As expected, the financing decision is related to several characteristics of the young firm. In particular, we find a concave effect of firm size: the higher the number of employees in small firms, the higher is the share of loan financing because young firms need to cover wage costs by external capital. Yet larger firms realise more sizable sales which contribute to covering wage costs and so the effect diminishes in larger firms. The effect of firm age is monotonically negative. The necessity of loan financing declines when firms mature and generate more sales to be used as an internal financing source. Incorporated firms have a lower share of loan financing because compulsory capital contributions of the owners can be used to finance initial investments and first operating costs. In addition, asset tangibility plays an important role: the higher the share of financed investments in total financing needs, the higher is the share of loans in the financing mix. Apparently, fixed assets are in fact used as collateral in loan financing. In contrast, there are no significant effects of firm profitability or the existence of high-skilled employees. Human capital of the employed personnel does not influence firms' financing structure.

This also holds true for human capital of the founders themselves: university graduates use neither more nor less loan financing than non-academic starters. What is more, all other included indicators for founders' socio-demographics turn out insignificant as well. Neither gender nor migrational status, neither general nor specific entrepreneurial experience contribute to explaining financial leverage. However, necessity entrepreneurs use less loan financing than opportunity entrepreneurs. On the one hand, starters from unemployment are often eligible for start-up subsidies. On the other hand, necessity entrepreneurs rely on informal money

\footnotetext{
${ }^{7}$ The results were obtained using the statistical software package STATA, version 11 . To estimate the bivariate Tobit model we applied the STATA-based programme mvtobit, written by Mikkel Barslund.
} 
Table 4: Estimation of the financing equation

\begin{tabular}{|c|c|c|c|c|c|c|c|c|c|}
\hline \multirow{2}{*}{$\begin{array}{l}\text { Dependent variable: } \\
\text { Share of loan financing }\end{array}$} & \multicolumn{3}{|c|}{$\begin{array}{c}(1) \\
\text { Single-equation Tobit }\end{array}$} & \multicolumn{3}{|c|}{$\begin{array}{c}(2) \\
\text { Single-equation Tobit }\end{array}$} & \multicolumn{3}{|c|}{$\begin{array}{c}\text { (3) } \\
\text { Two-equation Tobit }\end{array}$} \\
\hline & Coeff. & \multicolumn{2}{|l|}{$\begin{array}{l}\text { Robust } \\
\text { std. err. }\end{array}$} & Coeff. & \multicolumn{2}{|l|}{$\begin{array}{l}\text { Robust } \\
\text { std. err. }\end{array}$} & Coeff. & \multicolumn{2}{|l|}{$\begin{array}{l}\text { Robust } \\
\text { std. err. }\end{array}$} \\
\hline R\&D intensity & 0.028 & 0.029 & & 0.028 & 0.029 & & 0.441 & 0.071 & $* * *$ \\
\hline Number of employees (ln) & 0.122 & 0.034 & $* * *$ & 0.122 & 0.034 & $* * *$ & 0.105 & 0.032 & $* * *$ \\
\hline Number of employees $(\ln )^{2}$ & -0.019 & 0.012 & & -0.019 & 0.012 & & -0.013 & 0.011 & \\
\hline Profitability & -0.044 & 0.034 & & -0.044 & 0.034 & & -0.025 & 0.029 & \\
\hline Profitability * incorporated firm & 0.045 & 0.034 & & 0.045 & 0.034 & & 0.029 & 0.030 & \\
\hline Incorporated firm & -0.046 & 0.027 & * & -0.047 & 0.027 & $*$ & -0.065 & 0.026 & $* *$ \\
\hline Investments/financing needs & 0.399 & 0.040 & $* * *$ & 0.399 & 0.040 & $* * *$ & 0.333 & 0.040 & $* * *$ \\
\hline Firm age: $\quad 2$ years & -0.082 & 0.025 & $* * *$ & -0.082 & 0.025 & $* * *$ & -0.079 & 0.024 & $* * *$ \\
\hline 3 years & -0.159 & 0.027 & $* * *$ & -0.159 & 0.027 & $* * *$ & -0.148 & 0.026 & $* * *$ \\
\hline 4 years & -0.184 & 0.036 & $* * *$ & -0.184 & 0.036 & $* * *$ & -0.181 & 0.034 & $* * *$ \\
\hline Team of entrepreneurs & 0.008 & 0.026 & & 0.007 & 0.026 & & 0.017 & 0.025 & \\
\hline Employees with required univ. degree & -0.022 & 0.032 & & -0.022 & 0.032 & & -0.033 & 0.031 & \\
\hline Entrepreneur with university degree & 0.018 & 0.023 & & 0.018 & 0.023 & & 0.002 & 0.022 & \\
\hline Female entrepreneurs only & 0.021 & 0.034 & & 0.021 & 0.034 & & 0.021 & 0.032 & \\
\hline Entrepreneurs with foreign origin only & 0.057 & 0.047 & & 0.058 & 0.047 & & 0.043 & 0.046 & \\
\hline Age of the oldest entrepreneur (ln) & -0.010 & 0.042 & & & & & & & \\
\hline Positive entrepreneurial experience & -0.001 & 0.027 & & -0.002 & 0.027 & & -0.005 & 0.026 & \\
\hline Negative entrepren. experience only & -0.009 & 0.032 & & -0.010 & 0.032 & & -0.019 & 0.030 & \\
\hline Necessity entrepreneur & -0.087 & 0.029 & $* * *$ & -0.088 & 0.028 & $* * *$ & -0.084 & 0.027 & $* * *$ \\
\hline Personal wealth/financing needs & -0.005 & 0.001 & $* * *$ & -0.005 & 0.001 & $* * *$ & -0.005 & 0.001 & $* * *$ \\
\hline Dummy for missing values & -0.083 & 0.022 & $* * *$ & -0.084 & 0.022 & $* * *$ & -0.086 & 0.020 & $* * *$ \\
\hline \multicolumn{10}{|l|}{ Industry (ref. consumer-or. services) } \\
\hline Cutting-edge technology manuf. & 0.032 & 0.051 & & 0.032 & 0.051 & & -0.009 & 0.050 & \\
\hline High-technology manufacturing & 0.062 & 0.051 & & 0.061 & 0.051 & & 0.042 & 0.049 & \\
\hline Technology-intensive services & -0.080 & 0.041 & $* *$ & -0.080 & 0.041 & $* *$ & -0.075 & 0.038 & * \\
\hline Software & -0.173 & 0.056 & $* * *$ & -0.172 & 0.055 & $* * *$ & -0.167 & 0.051 & $* * *$ \\
\hline Non-high-tech manufacturing & 0.049 & 0.041 & & 0.049 & 0.041 & & 0.043 & 0.039 & \\
\hline Skill-intensive services & -0.025 & 0.047 & & -0.025 & 0.047 & & -0.026 & 0.045 & \\
\hline Other business-oriented services & 0.006 & 0.050 & & 0.006 & 0.050 & & -0.001 & 0.048 & \\
\hline Construction & 0.001 & 0.041 & & 0.002 & 0.041 & & -0.001 & 0.040 & \\
\hline Wholesale and retail trade & -0.013 & 0.040 & & -0.013 & 0.040 & & -0.009 & 0.038 & \\
\hline Observation year 2008 & 0.080 & 0.020 & $* * *$ & 0.080 & 0.020 & $* * *$ & 0.071 & 0.019 & $* * *$ \\
\hline Integer & -0.494 & 0.156 & $* * *$ & -0.530 & 0.050 & $* * *$ & -0.474 & 0.052 & $* * *$ \\
\hline$\sigma$ & 0.440 & 0.012 & $* * *$ & 0.440 & 0.012 & $* * *$ & 0.433 & 0.012 & $* * *$ \\
\hline$\rho$ & & & & & & & -0.582 & 0.047 & $* * *$ \\
\hline Number of observations & & 1,299 & & & 4,299 & & & 299 & \\
\hline Log pseudolikelihood & & 708.77 & & & 708.80 & & & 104.90 & \\
\hline Pseudo $\mathrm{R}^{2}$ & & .175 & & & .175 & & & .173 & \\
\hline
\end{tabular}

Standard errors are clustered by firm identifier. */**/*** 10\%/5\%/1\% level of significance. Additional control variable indicating firms promoted by KfW included. Base category: consumer oriented service firm, observed in its founding year 2007, no member of the team of founders has previous entrepreneurial experience at the time of start-up. All absolute values used to calculate ratios are trimmed by excluding values below the 1st or above the 99th percentiles.

Data source: KfW/ZEW Start-up Panel. 
from family and friends to a higher degree. The effect of founders' personal wealth on the share of loan financing is significantly negative. More wealthy entrepreneurs can put higher amounts of own money into their business and therefore reduce the necessity of using loans to meet given financial needs.

Controlling for a broad range of firm and entrepreneur-related characteristics, there are only few differences with respect to industry. Compared to firms operating in the reference industry 'consumer-oriented services', software firms and technology-intensive service firms have a lower share of loan financing. Start-ups in these industries often require specific human capital and produce intangible assets. This reduces the extent of loan financing.

Finally, the effect of $R \& D$ intensity estimated in specification (1) turns out insignificant and negligible in size. The negative correlation of loan share and R\&D intensity observed in the bivariate comparison above thus results from selection of firms based on third-party variables $x$ and $z$. The share of loan financing is mainly determined by requirements of the start-up project while socio-demographic characteristics of the entrepreneurs only play a negligible role. It is therefore valid to leave out insignificant personal characteristics from the estimation. Specification (2) in Table 4 specifically leaves out age of the entrepreneur from the list of covariates. This exclusion also makes sense from an economic point of view. From a demandside perspective, business starters direct the financing structure to the needs of their projects and - controlling for other personal characteristics such as industry experience - start-up projects do not differ systematically between age groups. From a supply-side perspective, banks focus on the expected quality of the project and the reliability of the entrepreneur. They may take human capital of the entrepreneur, and in particular educational attainment and previous start-up experience, as a signal for creditworthiness (Werner, 2007). Yet within the range of prime age, age itself plays no role.

The coefficients estimated in specification (2) - including the effect of R\&D intensity - do basically not differ from those estimated in specification (1). This result substantiates the exclusion restriction discussed above. ${ }^{8}$

\footnotetext{
${ }^{8}$ In an additional specification (results available from the authors upon request) we leave out all person-related variables. Again, the estimated coefficients of the firm variables including R\&D intensity stay basically the same.
} 


\subsection{Determinants of R\&D Intensity: Single Equation Approach}

Turning to the determinants of $R \& D$ intensity, we note that the distribution of $R \& D$ intensity $r d i n t_{i}$ also has a mass point at the value of zero because the majority of young firms do not conduct own R\&D activities. We thus specify

$$
\begin{aligned}
& r_{\text {dint }}=\max \left(0, \text { rdint }_{i}^{*}\right) \geq 0, \\
& \text { rdint }_{i}^{*}=\text { loanshare }_{i} \gamma_{2}+z_{i} \alpha_{2}+x_{i} \beta_{2}+u_{2 i}
\end{aligned}
$$

in notational analogy to equation (1). Columns (1) and (2) of Table 5 report results from the single equation Tobit model of the $R \& D$ equation.

First of all, there are considerable differences across industries. Firms operating in cuttingedge or high-technology manufacturing, in technology-intensive services, or in the software industry have a higher $R \& D$ intensity. This result reflects the definition of high-tech industries which explicitly uses the (industry average) ratio of R\&D expenditure to total sales (cf. Table 6 in the appendix). However, there is also sizeable heterogeneity within the non-hightech sector. Non-high-tech manufacturers and skill-intensive service firms have a higher R\&D intensity than firms in the reference sector 'consumer-oriented services', while the lowest R\&D intensity is observed in the construction industry.

In addition to industry differences, both firm characteristics and personal characteristics of the entrepreneurs play a significant role in both specifications (1) and (2). We find an inverted Ushape pattern for the effect of firm size: on the one hand, small firms with no or very few employees do usually not employ research personnel and seldom conduct R\&D projects. On the other hand, research expenditure declines in relative terms as firms grow large. Incorporated firms, which usually have a more formalised organisational structure than non-incorporated firms, have a higher R\&D intensity. A higher share of investment costs in total financing needs also comes along with a higher R\&D intensity: physical capital and R\&D activity are often complements in firms' production process. Investments in large, specialised machinery for $R \& D$ purposes clearly increase the amount $R \& D$ expenditure.

Moreover, engagement in $R \& D$ requires some human capital intensity. As a consequence firms founded by academic entrepreneurs as well as those employing workers with a university degree are significantly more R\&D-intensive. Founders’ previous entrepreneurial experience - both positive and negative - also comes along with a higher R\&D intensity. Apparently, experienced entrepreneurs judge the importance of R\&D more easily and put a higher 
Table 5: Estimation of the R\&D equation

\begin{tabular}{|c|c|c|c|c|c|c|c|c|c|}
\hline \multirow{2}{*}{$\begin{array}{l}\text { Dependent variable: } \\
\text { R\&D intensity }\end{array}$} & \multicolumn{3}{|c|}{$\begin{array}{c}(1) \\
\text { Single-equation Tobit }\end{array}$} & \multicolumn{3}{|c|}{$\begin{array}{c}(2) \\
\text { Single-equation Tobit }\end{array}$} & \multicolumn{3}{|c|}{$\begin{array}{c}\text { (3) } \\
\text { Two-equation Tobit }\end{array}$} \\
\hline & Coeff. & $\begin{array}{l}\text { Robust } \\
\text { std. err. }\end{array}$ & & Coeff. & $\begin{array}{l}\text { Robust } \\
\text { std. err. }\end{array}$ & & Coeff. & $\begin{array}{l}\text { Robust } \\
\text { std. err. }\end{array}$ & \\
\hline Share of loan financing & -0.059 & 0.123 & & -0.053 & 0.124 & & 1.585 & 0.292 & $* * *$ \\
\hline Number of employees (ln) & 0.158 & 0.065 & $* *$ & 0.160 & 0.066 & $* *$ & 0.118 & 0.058 & $* *$ \\
\hline Number of employees $(\ln )^{2}$ & -0.053 & 0.021 & $* *$ & -0.053 & 0.021 & $* *$ & -0.039 & 0.019 & $* *$ \\
\hline Profitability & -0.091 & 0.079 & & -0.092 & 0.079 & & -0.059 & 0.064 & \\
\hline Profitability * incorporated firm & 0.089 & 0.079 & & 0.089 & 0.079 & & 0.057 & 0.064 & \\
\hline Incorporated firm & 0.355 & 0.069 & $* * *$ & 0.351 & 0.068 & $* * *$ & 0.326 & 0.060 & $* * *$ \\
\hline Investments/financing needs & 0.462 & 0.104 & $* * *$ & 0.461 & 0.104 & $* * *$ & 0.266 & 0.081 & $* * *$ \\
\hline Firm age: $\quad 2$ years & 0.079 & 0.054 & & 0.081 & 0.054 & & 0.119 & 0.052 & $* *$ \\
\hline 3 years & 0.075 & 0.051 & & 0.075 & 0.051 & & 0.129 & 0.050 & ** \\
\hline 4 years & 0.011 & 0.065 & & 0.011 & 0.066 & & 0.049 & 0.062 & \\
\hline Team of entrepreneurs & -0.075 & 0.051 & & -0.075 & 0.051 & & -0.063 & 0.046 & \\
\hline Employees with required univ. degree & 0.204 & 0.054 & $* * *$ & 0.205 & 0.054 & $* * *$ & 0.197 & 0.052 & $* * *$ \\
\hline Entrepreneur with university degree & 0.236 & 0.051 & $* * *$ & 0.233 & 0.051 & $* * *$ & 0.195 & 0.044 & $* * *$ \\
\hline Female entrepreneurs only & -0.115 & 0.077 & & -0.116 & 0.077 & & -0.113 & 0.072 & \\
\hline Entrepreneurs with foreign origin only & -0.026 & 0.088 & & -0.031 & 0.088 & & -0.081 & 0.085 & \\
\hline Age of the oldest entrepreneur (ln) & -0.215 & 0.081 & $* * *$ & -0.223 & 0.082 & $* * *$ & -0.191 & 0.074 & $* *$ \\
\hline Positive entrepreneurial experience & 0.180 & 0.055 & $* * *$ & 0.179 & 0.055 & $* * *$ & 0.157 & 0.050 & $* * *$ \\
\hline Negative entrepren. experience only & 0.092 & 0.052 & * & 0.095 & 0.053 & * & 0.061 & 0.050 & \\
\hline Necessity entrepreneur & -0.105 & 0.061 & $*$ & -0.104 & 0.061 & * & -0.085 & 0.057 & \\
\hline Personal wealth/financing needs & 0.000 & 0.001 & & & & & & & \\
\hline Dummy for missing value & -0.057 & 0.037 & & & & & & & \\
\hline Industry (ref. consumer-or. services) & & & & & & & & & \\
\hline Cutting-edge technology manuf. & 0.461 & 0.120 & $* * *$ & 0.469 & 0.121 & $* * *$ & 0.395 & 0.106 & $* * *$ \\
\hline High-technology manufacturing & 0.362 & 0.092 & $* * *$ & 0.362 & 0.092 & $* * *$ & 0.286 & 0.086 & $* * *$ \\
\hline Technology-intensive services & 0.145 & 0.081 & * & 0.150 & 0.082 & $*$ & 0.158 & 0.075 & $* *$ \\
\hline Software & 0.375 & 0.090 & $* * *$ & 0.379 & 0.091 & $* * *$ & 0.378 & 0.085 & $* * *$ \\
\hline Non-high-tech manufacturing & 0.141 & 0.079 & * & 0.144 & 0.079 & $*$ & 0.092 & 0.075 & \\
\hline Skill-intensive services & 0.148 & 0.085 & * & 0.152 & 0.085 & $*$ & 0.138 & 0.080 & $*$ \\
\hline Other business-oriented services & -0.064 & 0.098 & & -0.060 & 0.098 & & -0.082 & 0.094 & \\
\hline Construction & -0.278 & 0.104 & $* * *$ & -0.273 & 0.103 & $* * *$ & -0.247 & 0.097 & $* *$ \\
\hline Wholesale and retail trade & -0.155 & 0.094 & $*$ & -0.150 & 0.094 & & -0.142 & 0.088 & \\
\hline Observation year 2008 & -0.097 & 0.039 & $* *$ & -0.095 & 0.039 & $* *$ & -0.082 & 0.035 & $* *$ \\
\hline Integer & -0.540 & 0.307 & $*$ & -0.534 & 0.306 & $*$ & -0.567 & 0.280 & $* *$ \\
\hline$\sigma$ & 0.716 & 0.089 & $* * *$ & 0.716 & 0.089 & $* * *$ & 0.704 & 0.085 & $* * *$ \\
\hline$\rho$ & & & & & & & -0.582 & 0.047 & $* * *$ \\
\hline Number of observations & & 4,299 & & & 4,299 & & & 4,299 & \\
\hline Log pseudolikelihood & & ,721.31 & & &, 722.56 & & & 404.90 & \\
\hline Pseudo R² & & 0.159 & & & 0.158 & & & 0.173 & \\
\hline
\end{tabular}

Standard errors are clustered by firm identifier. */**/*** 10\%/5\%/1\% level of significance. Additional control variable indicating firms promoted by KfW included. Base category: consumer oriented service firm, observed in its founding year 2007, no member of the team of founders has previous entrepreneurial experience at the time of start-up. All absolute values used to calculate ratios are trimmed by excluding values below the 1st or above the 99th percentiles.

Data source: KfW/ZEW Start-up Panel. 
weight on their own R\&D activities. Firms run by female entrepreneurs are slightly less inclined to do $R \& D$, and so are firms started by older entrepreneurs. On the contrary, personal wealth of the founders has no effect on R\&D intensity. The decision to do R\&D and the extent of necessary R\&D expenditure are closely related to the business idea itself and the knowledge intensity of the involved technology. With respect to the evolution of researchbased business ideas, human capital is more important than private wealth. As it turns out, the estimated coefficient of private wealth is both negligible in size and statistically insignificant. Consequently, it is reasonable to exclude the private wealth variable from the $R \& D$ equation. Estimates from the reduced specification (2) in Table 5 are basically the same as the results from the baseline specification (1).

Controlling for firm and entrepreneur-related characteristics, the effect of loan share on R\&D intensity turns out negligible and statistically insignificant in both specifications (1) and (2). Comparing this result to the negative correlation observed in bivariate comparison emphasises the importance to account for selection based on third-party variables.

\subsection{Accounting for Simultaneity of Financial Leverage and R\&D Intensity}

The selection based on observable characteristics is such that firms opt for a particular financing structure and, at the same time, choose an R\&D regime. Looking at, for instance, the effect of incorporation, the necessity for loan financing goes down (due to equity financing of the owners). At the same time, corporate firms are more R\&D intensive than non-incorporated ones. Disregarding the effects of firm and entrepreneur-related differences results in a spuriously negative correlation between R\&D intensity and the share of loan financing. However, it is likely that both variables of interest are additionally affected by common unobserved shocks. In this case, the error terms of equations (1) and (2) would be correlated across equations.

In order to account for this possibility, we employ a bivariate Tobit model and estimate equations (1) and (2) simultaneously, assuming joint normality of the error terms $\left(u_{1 i}, u_{2 i}\right) \sim N\left(0 ; \sigma_{1}^{2}, \sigma_{2}^{2}, \rho_{12}\right)$, with variances $\sigma_{1}^{2}$ and $\sigma_{2}^{2}$ and correlation coefficient $\rho_{12}$. Identification is achieved by excluding age of the entrepreneur from equation (1) and personal wealth from equation (2). As discussed above, age of the entrepreneur is significantly correlated to $R \& D$ intensity but can reasonably be assumed to have no effect on the share of loan financing. Analogously, entrepreneurs' private wealth has an effect on financing decisions but 
is not related to R\&D intensity. Estimated coefficients for the two equations are displayed in columns (3) of Table 4 and Table 5, respectively.

Most importantly, the effects of the respective endogenous regressors turn positive and significant. An increase in $R \& D$ intensity ceteris paribus results in an increase in the share of loan financing. In turn, an increase in the share of loan financing ceteris paribus results in an increase in $R \& D$ intensity. The stability condition $\gamma_{1} \cdot \gamma_{2}<1$ is fulfilled and the estimation is logically consistent (Amemiya, 1974): $\hat{\gamma}_{1} \cdot \hat{\gamma}_{2}=0.699<1$ at a p-value of 0.03 .

While the estimated impacts of covariates do hardly change in comparison to the singleequation estimates discussed above, the estimated correlation $\hat{\rho}_{12}$ is negative and highly significant. In addition to selection based on observables, unobserved factors are correlated negatively across equations. For instance, adverse random shocks restricting firms’ liquidity might increase the necessity of loan financing and, at the same time, make firms cut back their R\&D expenditure. If we take this effect into account, $R \& D$ intensity and the share of loan financing in young firms are in fact positively related.

Our central result is related to Savignac's (2008) finding that the existence of financing constraints restrains the probability of innovation activities. However, the recursive probit approach chosen by Savignac restricts the relationship of financing and innovation to be onedirectional. The same drawback holds for the probit approach of Winston Smith (2010), who estimates the probability of patents, instrumenting financial leverage. Baldwin et al. (2002) estimate regressions for both the share of long-term debt and R\&D investment of Canadian firms, and report a negative relationship between these two variables. This finding differs from our key result. The likely reason is that, while employing 2 SLS estimations to instrument both variables of interest, Baldwin et al. (2002) do not estimate their equations simultaneously and thus disregard the negative cross-equation correlation.

\section{Conclusion}

R\&D activities are a decisive mean for newly founded firms to gain a competitive advantage over their rivals and to establish themselves in the market. However, R\&D activities incur high costs that are difficult to bear in particular for young firms (Hall, 2002; Hall and Learner Learner, 2010). Expenditure on R\&D often exceeds young firms’ internal financing capacity and induces firms to draw on external financing. The interrelation of R\&D activities and financial leverage as measured by the share of loan financing in total financing needs is at heart 
of this paper. Our empirical analyses are based on the first two survey waves of the KfW/ZEW Start-up Panel, a unique data set on business start-ups in Germany that combines firm information with entrepreneur-related specifics.

Single-equation estimates of the financing equation reveal that the share of loan financing is mainly determined by firm-specific variables derived from traditional theories of corporate finance like static trade-off theory or variants of the pecking order hypothesis (cp. Chang et al. 2009). Entrepreneur-specific variables only play a subordinate role for explaining firms’ financial leverage. Given the importance of the entrepreneur in newly founded firms, this result is surprising at first sight. However, it shows that from a demand-side perspective, founders' financing preferences are strongly guided by the requirements of their start-up projects which are in turn captured by the broad set of firm variables (Kohn and Ullrich, 2010). From a supply-side perspective, banks may take observable characteristics of the founders as an initial signal for creditworthiness, but the importance of this signal declines rapidly even in the first few years of firms' existence. On the contrary, both firm-specific and entrepreneurspecific variables are decisive for the level of a firm’s R\&D intensity.

One outstanding result of the simultaneous two-equation model is the fact that the coefficient estimates for the exogenous covariates hardly differ between the single-equation models and the bivariate model. This result underlines the robustness of our findings with respect to the choice of exogenous covariates. The estimated effects of the endogenous regressors do differ between the respective models, though. Whereas descriptive statistics even mitigate in favour of a negative relationship between the share of loan financing and R\&D intensity, results of single-equation estimates do not show any significant relationship. This finding hints towards selection based on observables in both $\mathrm{R} \& \mathrm{D}$ intensity and financial leverage. What is more, the simultaneous equation model reveals that there is a significantly positive interrelation but unobserved random shocks are negatively correlated across the two equations. In response to adverse idiosyncratic shocks, firms may cut back their R\&D expenditure while simultaneously the need for external loan financing increases.

We conclude that financial leverage and R\&D activity are in fact interdependent and positively related. One drawback of present study is the cross-sectional set-up of the empirical analysis. Future research aiming at the innovation-financing relationship may use longer-term panel data sets which would allow researchers to examine changes of young firms' capital structure over time, and to analyse how these changes might be traced back to R\&D activities in the past. 


\section{References}

Achleitner, A.-K., R. Braun and K. Kohn (2011), New Venture Financing in Germany: Effects of Firm and Owner Characteristics, Zeitschrift für Betriebswirtschaft, 81 (3), 263-294.

Adedeji, A. A. (2002), A Cross-sectional Test of Pecking Order Hypothesis against Static Trade-off Theory on UK Data, http://ssrn.com/abstract=302827.

Amemiya, T. (1974), Multivariate regression and simultaneous equation models when the dependent variables are truncated normal, Econometrica, 42 (6), 999-1012.

Ang, J. S. (1992), On the theory of finance for privately held firms, Journal of Small Business Finance, 1, 185-203.

Astebro, T., and I. Bernhardt (2003), Start-up financing, owner characteristics, and survival, Journal of Economics \& Business, 55, 303-319.

Baldwin J. R., V. Gaudreault and G. Gellatly (2002), Financing Innovation in New Small Firms: New Evidence from Canada, Analytical Studies Branch Research Paper Series No. 190.

Bhaird, C., and B. Lucey (2010), Determinants of capital structure in Irish SMEs, Small Business Economics, 35 (3), 357-375.

Blanchflower, D. G., P. B. Levine and D. J. Zimmerman (2003), Discrimination in the small business credit market, Review of Economics and Statistics, 85, 930-943.

Bond, S., D. Harhoff and J. Van Reenen (2005), Investment, R\&D and Financial Constraints in Britain and Germany, Annales d'Economie et de Statistique, 79/80 (Special Issue), 433-460.

Cassar, G. (2004), The financing of business start-ups, Journal of Business Venturing, 19, 261-283.

Cavalluzzo, K., and L. Cavalluzzo (1998), Market structure and discrimination: The case of small businesses, Journal of Money, Credit, and Banking, 30, 771-792.

Chang, C., A. C. Lee and C. F. Lee (2009), Determinants of Capital Structure Choice: A Structural Equation Modelling Approach, Quarterly Review of Economics and Finance, 49, 197-213.

Chirinko, R. S., and A. R. Singha (2000), Testing Static Tradeoff against Pecking Order models of Capital Structure: A Critical Comment, Journal of Financial Economics, 58, 417-425.

Cohen, W. M., and R. C. Levin (1989), Empirical Studies of Innovation and Market Structure, in: R. Schmalensee and R. D. Willig (eds.), Handbook of Industrial Organization, Vol. II, North Holland, Amsterdam, 1059-1107.

Cole, R. A. (2008), What Do We Know About the Capital Structure of Privately Held Firms? Evidence from the Surveys of Small Business Finance, http://ssrn.com/paper=1013085.

Coleman, S., and A. Robb (2009), A comparison of new firm financing by gender: evidence from the Kauffman Firm Survey data, Small Business Economics, 33, 397-411.

Conover, W. J. (1999), Practical Nonparametric Statistics, $3^{\text {rd }}$ edn., New York et al.: Wiley.

Cosh, A., D. Cumming and A. Hughes (2009), Outside Entrepreneurial Capital, Economic Journal, 119 (540), 1494-1533. 
Czarnitzki, D. (2006), Research and Development in Small and Medium-Sized Enterprises: The Role of Financial Constraints and Public Funding, Scottish Journal of Political Economy, 53 (3), 335-357.

Czarnitzki, D., and H. Hottenrott (2011), R\&D Investment and Financing Constraints of Small and Medium-sized Firms, Small Business Economics, 36 (1), 65-83.

Czarnitzki, D., and K. Kraft (2009), Capital Control, Debt Financing and Innovative Activity, Journal of Economic Behavior and Organization, 71, 372-383.

Czarnitzki, D., and K. Kraft (2010), On the Profitability of Innovative Assets, Applied Economics, 42 (15), 1941-1953.

Eckhardt, J., S. Shane and F. Delmar (2006), Multi-stage selection and the financing of new ventures, Management Science, 52 (2), 220-232.

EUROSTAT (2010), Business enterprise R\&D expenditure (BERD) by economic activity and type of costs, Extracted: 2010/08/31.

Frank, M. Z., and V. K. Goyal (2008), Trade-off and Pecking Order Theories of Debt, in: B. Espen Eckbo (ed.), Handbook of Corporate Finance: Empirical Corporate Finance, Vol. 2, Elsevier/North-Holland, Amsterdam, 135-202.

Frielinghaus, A., B. Mostert and C. Firer (2005), Capital structure and the firm's life stage, South African Journal of Business Management, 36 (4), 9-18.

Fryges, H., S. Gottschalk and K. Kohn (2010), The KfW/ZEW Start-up Panel: Design and Research Potential, Schmollers Jahrbuch, 130 (1), 117-131.

Geroski, P., S. Machin and J. van Reenen (1993), The Profitability of Innovating Firms, RAND Journal of Economics, 24 (2), 198-211.

Gompers, P., and J. Lerner (2006), The Venture Capital Cycle, Cambridge, MA: MIT Press.

Gorodnichenko, Y., and M. Schnitzer (2010), Financial Constraints and Innovation: Why Poor Countries Don't Catch Up, NBER Working Paper No. 15792.

Hagen, T., K. Kohn, and K. Ullrich (2011), KfW-Gründungsmonitor 2011. Dynamisches Gründungsgeschehen im Konjunkturaufschwung, KfW Bankengruppe, Frankfurt.

Hall, B. H. (2002), The Financing of Research and Development, Oxford Review of Economic Policy, 18 (1), 35-51.

Hall, B. H., and J. Lerner (2010), The Financing of R\&D and Innovation, in: B. H. Hall and N. Rosenberg (eds.), Handbook of the Economics of Innovation, Elsevier/North Holland, Amsterdam, 610-638.

Hall, B. H., F. Lotti and J. Mairesse (2009), Innovation and Productivity in SMEs: Empirical Evidence for Italy, Small Business Economics, 33, 13-33.

Heaton, J. C., and D. J. Lucas (2004), Capital Structure, Hurdle Rates, and Portfolio Choice Interactions in an Entrepreneurial Firm, Working Paper, Northwestern University.

Heger, D., and T. Tykvova (2009), Do Venture Capitalists Give Founders Their Walking Papers?, Journal of Corporate Finance, 15 (5), 613-625.

Hellmann, T., and M. Puri (2000), Interaction between product market and financing strategy: The role of venture capital, Review of Financial Studies, 13 (4), 959-984.

Himmelberg, C. P., and B. C. Petersen (1994), R\&D and Internal Finance: A Panel Study of Small Firms in High-Tech Industries, Review of Economics and Statistics, 76 (1), 3851. 
Hottenrott, H., and B. Peters (2011), Innovative Capability and Financing Constraints for Innovation: More Money, More Innovation?, Review of Economics and Statistics, forthcoming.

Hutchinson, R. W. (1995), The Capital Structure and Investment Decision of the Small Owner-Managed Firm: Some Exploratory Issues, Small Business Economics, 7 (3), 231239.

Jensen, M. C., and W. H. Meckling (1976), Theory of the firm: Managerial behavior, agency costs and ownership structure, Journal of Financial Economics, 3 (4), 305-360.

Kamien, M. I., and N. L. Schwartz (1982), Market Structure and Innovation, Cambridge University Press.

Kohn, K., and H. Spengler (2008), Finanzierungsstruktur von Existenzgründungen in Deutschland, FINANZ BETRIEB 10 (1), 72-76.

Kohn, K., and K. Ullrich (2010), Starten Frauen tatsächlich kleinere Unternehmen? Dimensionen der Gründungsgröße näher betrachtet, Betriebswirtschaftliche Forschung und Praxis, 62 (6), 654-681.

Legler, H., and R. Frietsch (2006), Neuabgrenzung der Wissenswirtschaft - forschungsintensive Industrien und wissensintensive Dienstleistungen (NIW/ISI-Listen 2006), Studien zum deutschen Innovationssystem Nr. 22-2007, Karlsruhe, Hanover.

López-Gracia, J., and F. Sogorb-Mira (2008), Testing trade-off and pecking order theories financing SMEs, Small Business Economics, 31 (2), 117-136.

Mairesse, J., and P. Mohnen (2010), Using Innovation Surveys For Econometric Analysis, in: B. H. Hall and N. Rosenberg (eds.), Handbook of the Economics of Innovation, Elsevier/North Holland, Amsterdam, 1130-1155.

Myers, S. C. (1984), The capital structure puzzle, Journal of Finance, 39 (3), 575-592.

Nyström, K. (2009), Firm Size, Firm Maturity and Product and Process R\&D in Swedish Manufacturing Firms, in: C. Karlsson, B. Johansson and R. R. Stough (eds.): Innovations and Entrepreneurship in Functional Regions, Cheltenham: Edward Elgar, 107-139.

Petersen, M. A., and R. G. Rajan (1994), The benefits of lending relationships: evidence from small business data, Journal of Finance, 49 (1), 3-37.

Rammer, C. (2009), Innovationsverhalten der Unternehmen in Deutschland 2007 - Aktuelle Entwicklungen und die Rolle der Finanzierung, Studien zum deutschen Innovationssystem 04-2009, Berlin.

Romer, P. M. (1990), Endogenous Technological Change, Journal of Political Economy, 98 (5), 71-102.

Ross, S. A. (1977), The Determination of Financial Structure: The Incentive-Signalling Approach, Bell Journal of Economics, 8 (1), 23-40.

Savignac, F. (2008), Impact of Financial Constraints on Innovation: What Can Be Learned from a Direct Measure?, Economics of Innovation and New Technology, 17 (6), 553-569.

Shyam-Sunder, L., and S. C. Myers (1999), Testing Static Trade-off against Pecking Order Models of Capital Structure, Journal of Financial Economics, 51, 219-244.

Storey, D. J. (1994), The role of legal status in influencing bank financing and new firm growth, Applied Economics, 26, 129-136. 
Van der Panne, G., C. van Beers and A. Kleinknecht (2003), Success and Failure of Innovation: A Literature Review, International Journal of Innovation Management, 7 (3), 309-338.

Verheul, I., and R. Thurik (2001), Start-up Capital: “Does Gender Matter?”, Small Business Economics, 16, 329-345.

Werner, A. (2007), Entrepreneurial Signaling - Eine theoretische und empirische Analyse des Einflusses von höheren Bildungssignalen und Patenten auf innovative Unternehmensgründungen, Munich and Mering: Rainer Hampp.

Winston Smith, S. (2010), Beg, borrow, and deal? Entrepreneurship and financing in new firm innovation, Discussion Paper, Temple University, Philadelphia, http://ssrn.com/abstract=1573685.

Wooldridge, J. M. (2001), Econometric Analysis of Cross Section and Panel Data, Cambridge, MA: MIT Press. 


\section{Appendix}

Table 6: Composition of industry sectors

\begin{tabular}{|c|c|c|}
\hline & Sector & NACE Rev. 1.1 \\
\hline & \multicolumn{2}{|l|}{ High-technology industries } \\
\hline 1 & Cutting-edge technology manufacturing & $\begin{array}{l}\text { 23.30, 24.20, 24.41, 24.42, 29.60, 30.02, } \\
32.10,32.20,32.30,33.10,33.20,33.30 \\
35.30\end{array}$ \\
\hline 2 & High-technology manufacturing & $\begin{array}{l}24.13-4,24.16-7,24.51,24.61,24.63-4, \\
24.66,25.11,25.13,26.15,29.11-4,29.24 \text {, } \\
\text { 29.31-2, 29.41-3, 29.52-6, 30.01, 31.10, } \\
\text { 31.20, 31.40, 31.50, 31.61-2, 33.40, 34.10, } \\
\text { 34.30, 35.20 }\end{array}$ \\
\hline 3 & Technology-intensive services & 64.3, 72 (without 72.2), 73.1, 74.2, 74.3 \\
\hline \multirow[t]{2}{*}{4} & Software supply and consultancy & 72.2 \\
\hline & Non-high-tech industries & \\
\hline 5 & Non-high-tech manufacturing & $15-37$ (without sectors $1+2$ ) \\
\hline 6 & Skill-intensive services (non-technical consulting services) & 73.2, 74.11-4, 74.4 \\
\hline 7 & Other business-oriented services & $\begin{array}{l}\text { 60.3, } 61,62,63.1-2,63.4,64.1,71.1-3 \text {, } \\
74.5-8 \text { (without 74.87.7), } 90\end{array}$ \\
\hline 8 & Consumer-oriented services & $\begin{array}{l}55,60.1-2,63.3,65-67,70,71.4,80.4,92 \text {, } \\
93\end{array}$ \\
\hline 9 & Construction & 45 \\
\hline 10 & Wholesale and retail trade (without trade agents) & $50-52$ (without 51.1) \\
\hline
\end{tabular}

Cutting-edge manufacturing technology: manufacturing industries with average R\&D expenditure $>7.0 \%$ of total sales. High-technology manufacturing: manufacturing industries with average R\&D expenditure $2.5-7.0 \%$ of total sales. Source: Legler and Frietsch (2006), own classification. 
Table 7: Financing structure, unweighted sample results

\begin{tabular}{|c|c|c|}
\hline & $\begin{array}{l}\text { Share of all firms using the source of } \\
\text { finance }(\%)\end{array}$ & Average share in total financing (\%) \\
\hline $\begin{array}{l}\text { Revenues from sales/retained } \\
\text { profits }\end{array}$ & 91.7 & 73.8 \\
\hline Founder's means & 46.0 & 16.4 \\
\hline \multirow[t]{2}{*}{ Capital from third parties } & 30.7 & 9.8 \\
\hline & $\begin{array}{c}\text { Share of all firms using capital from } \\
\text { third parties (\%) }\end{array}$ & $\begin{array}{c}\text { Average share in total capital received } \\
\text { from third parties (\%) }\end{array}$ \\
\hline Bank loans & 70.5 & 50.9 \\
\hline Promotional loans & 32.9 & 19.5 \\
\hline Relatives and friends & 19.0 & 10.7 \\
\hline $\begin{array}{l}\text { Subsidies from Federal } \\
\text { Employment Agency }\end{array}$ & 31.0 & 14.0 \\
\hline Equity capital & 8.8 & 4.9 \\
\hline Loan financing ${ }^{\mathrm{a}}$ & 81.8 & 70.4 \\
\hline
\end{tabular}

a Bank loans and promotional loans.

Data source: KfW/ZEW Start-up Panel.

Table 8: R\&D activities, unweighted sample results

\begin{tabular}{lccccc}
\hline & \# of ob- & \multicolumn{3}{c}{ Percentiles } \\
& $\begin{array}{c}\text { Mervations } \\
\text { serve }\end{array}$ & Mean & $50 \%$ & $75 \%$ \\
\hline Average expenditure on R\&D (Euro) & 1,748 & 31,800 & 3,000 & 12,300 & 40,000 \\
R\&D intensity (\%) & 1,383 & 37.4 & 2.2 & 7.6 & 21.4 \\
\hline
\end{tabular}

Numbers referring to firms conducting own R\&D activities. R\&D intensity measured as expenditure on R\&D over total sales. R\&D expenditure and total sales are trimmed by excluding values above the 99th percentiles.

Data source: KfW/ZEW Start-up Panel. 
Table 9: Definition and descriptive statistics of variables

\begin{tabular}{|c|c|c|c|}
\hline Variable & Operationalisation in the questionnaire & Mean & Median \\
\hline Share of loan financing & $\begin{array}{l}\text { How high were the proportions of different sources of external capi- } \\
\text { tal in the year 200X? [Loan financing includes the following catego- } \\
\text { ries: overdraft credit, other bank loans, promotional loans from KfW } \\
\text { or financial institutions of the German states.] }\end{array}$ & $6.7 \%$ & $0 \%$ \\
\hline R\&D intensity & $\begin{array}{l}\text { - How high were your expenses for research and development in- } \\
\text { cluding possible assignments to third parties in the previous year? } \\
\text { - What was the amount of sales in the year 200X? }\end{array}$ & $4.6 \%$ & $0 \%$ \\
\hline Number of employees & How many employees worked in your firm by 31/12/200X? & 3.4 & 2 \\
\hline Profitability & $\begin{array}{l}\text { Did your firm realise a profit or a loss before taxes in the year 200X? } \\
\text { How high was your firm's profit (loss) before taxes in the year } \\
200 X \text { ? }\end{array}$ & $3.5 \%$ & $10 \%$ \\
\hline Incorporated firm & [Dummy variable, identifier taken from Creditreform database.] & $31.6 \%$ & 0 \\
\hline Investments/financing needs & $\begin{array}{l}\text { - What was the amount of total investments in the year 200X? } \\
\text { - What was the amount of your operating costs in the year 200X? }\end{array}$ & $30.8 \%$ & $23.1 \%$ \\
\hline Firm age (in years) & $\begin{array}{l}\text { In which year was your firm established? [Initial founding year, not } \\
\text { mere change of ownership, name, or legal form.] }\end{array}$ & 2.3 & 2 \\
\hline Team of entrepreneurs & $\begin{array}{l}\text { Was your firm set up by one single founder or by a team of several } \\
\text { founders, owners, or shareholders? }\end{array}$ & $26.5 \%$ & 0 \\
\hline $\begin{array}{l}\text { Employees with required uni- } \\
\text { versity degree (dummy vari- } \\
\text { able) }\end{array}$ & $\begin{array}{l}\text { How many of your employees work in occupations requiring a uni- } \\
\text { versity degree? }\end{array}$ & $11.4 \%$ & 0 \\
\hline $\begin{array}{l}\text { Entrepreneur with university } \\
\text { degree }\end{array}$ & $\begin{array}{l}\text { Which is the highest professional qualification that the founder(s) } \\
\text { has (have) acquired? } \\
\text { [Tertiary education institutions comprise technical colleges, full } \\
\text { universities, and doctoral programmes.] }\end{array}$ & $40.5 \%$ & 0 \\
\hline Female entrepreneurs only & $\begin{array}{l}\text { Is the founder male or female? } \\
\text { How many of the founders are female? }\end{array}$ & $9.2 \%$ & 0 \\
\hline $\begin{array}{l}\text { Entrepreneurs with foreign } \\
\text { origin only }\end{array}$ & Which national origin does (do) the founder(s) have? & $5.3 \%$ & 0 \\
\hline $\begin{array}{l}\text { Age of the oldest entrepreneur } \\
\text { (in years) }\end{array}$ & $\begin{array}{l}\text { - In which year was the founder born? } \\
\text { - Please indicate the age of each founder. }\end{array}$ & 40.7 & 40 \\
\hline $\begin{array}{l}\text { Positive entrepreneurial experi- } \\
\text { ence }\end{array}$ & $\begin{array}{l}\text { Had (one of) the founder(s) already founded one or more firms } \\
\text { before the recent start-up? What happened to these firms? [Answers: } \\
\text { old firm continues to exist, was handed over to a family member or a } \\
\text { successor, or was sold.] }\end{array}$ & $20.1 \%$ & 0 \\
\hline $\begin{array}{l}\text { Negative entrepreneurial ex- } \\
\text { perience }\end{array}$ & $\begin{array}{l}\text { Had (one of) the founder(s) already founded one or more firms } \\
\text { before the recent start-up? What happened to these firms? [Answers: } \\
\text { old firm closed due to insolvency, closed without insolvency pro- } \\
\text { ceedings.] }\end{array}$ & $12.2 \%$ & 0 \\
\hline Necessity entrepreneur & $\begin{array}{l}\text { What was the main reason for the (members of the) founder (team) } \\
\text { to start working self-employed? [Necessity motives include the } \\
\text { following answers: There was no appropriate alternative option on } \\
\text { the labour market; To resort from unemployment.] }\end{array}$ & $16.7 \%$ & 0 \\
\hline $\begin{array}{l}\text { Personal wealth/financing } \\
\text { needs (non-missing values) }\end{array}$ & $\begin{array}{l}\text { - Aside from assets related to your firm, did you possess additional } \\
\text { private assets at the end of the year } 200 \mathrm{X} \text { ? } \\
\text { - Aside from liabilities resulting from your entrepreneurial activities, } \\
\text { did you have additional liabilities at the end of the year } 200 \mathrm{X} \text { ? }\end{array}$ & $500.6 \%$ & $30.4 \%$ \\
\hline $\begin{array}{l}\text { Missing information on per- } \\
\text { sonal wealth }\end{array}$ & [Dummy variable] & $29.9 \%$ & 0 \\
\hline
\end{tabular}

Descriptive statistics (unweighted) are displayed for the sample used for the bivariate regression. All absolute values used to calculate ratios are trimmed by excluding values below the 1st or above the 99th percentiles.

Data source: KfW/ZEW Start-up Panel. 